University of Nebraska - Lincoln

DigitalCommons@University of Nebraska - Lincoln

Papers in the Earth and Atmospheric Sciences

Earth and Atmospheric Sciences, Department

May 2004

\title{
Twentieth century water quality trends in Minnesota lakes compared with presettlement variability
}

Joy M. Ramstack

Lehigh University, jramstack@mbl.edu

Sherilyn C. Fritz

University of Nebraska-Lincoln, sfritz2@unl.edu

Daniel R. Engstrom

St. Croix Watershed Research Station, Science Museum of Minnesota, dre@smm.org

Follow this and additional works at: https://digitalcommons.unl.edu/geosciencefacpub

Part of the Earth Sciences Commons

Ramstack, Joy M.; Fritz, Sherilyn C.; and Engstrom, Daniel R., "Twentieth century water quality trends in Minnesota lakes compared with presettlement variability" (2004). Papers in the Earth and Atmospheric Sciences. 43.

https://digitalcommons.unl.edu/geosciencefacpub/43

This Article is brought to you for free and open access by the Earth and Atmospheric Sciences, Department of at DigitalCommons@University of Nebraska - Lincoln. It has been accepted for inclusion in Papers in the Earth and Atmospheric Sciences by an authorized administrator of DigitalCommons@University of Nebraska - Lincoln. 


\title{
Twentieth century water quality trends in Minnesota lakes compared with presettlement variability
}

\author{
Joy M. Ramstack, Sherilyn C. Fritz, and Daniel R. Engstrom
}

\begin{abstract}
A diatom-based transfer function was used to reconstruct water chemistry before European settlement in 55 Minnesota lakes. The lakes span three natural ecoregions, which differ in their history of land use, as well as in surficial geology, climate, and vegetation. Postsettlement trends were compared with water chemistry change reconstructed from two presettlement core sections (circa 1750 and 1800) as a measure of natural variability. Presettlement water quality changes were generally small and nondirectional in all three ecoregions. In contrast, half of the urban lakes showed a statistically significant increase in chloride, whereas $30 \%$ of urban and 30\% of agricultural region lakes record a statistically significant increase in total phosphorus between 1800 and the present. These changes, which are attributed to road salt and nutrient runoff, are strongly correlated with the percentage of watershed area that is developed (residential or urban) in the case of chloride increases and the percentage of developed (metropolitan areas) or agricultural (agricultural areas) land in the case of nutrient increases. Water quality has changed little since 1800 for lakes in the forested regions of northeastern Minnesota. The few changes that are seen in this region are likely related to natural variations in climate or catchment soils.
\end{abstract}

\begin{abstract}
Résumé : L'utilisation d'une fonction de transfert basée sur les diatomées nous a permis de reconstituer la chimie des eaux dans cinquante-cinq lacs du Minnesota avant l'établissement des européens. Les lacs se répartissent dans trois écorégions naturelles qui différent par l'utilisation que l'on a fait des terres dans le passé, ainsi que par la géologie de surface, le climat et la végétation. Nous avons comparé les tendances qui sont apparues après la colonisation avec les changements estimés à partir de deux sections de carottes datant d'avant la colonisation (vers 1750 et 1800) qui représentent la variabilité naturelle. Avant la colonisation, les changements de la qualité de l'eau dans les trois écorégions étaient généralement faibles et sans tendance marquée particulière. En revanche, entre 1800 et l'époque actuelle, la moitié des lacs urbains affichent une augmentation statistiquement significative des chlorures et $30 \%$ des lacs urbains et $30 \%$ des lacs des régions agricoles subissent une augmentation statistiquement significative du phosphore total. Il existe une forte corrélation entre ces changements, qui sont attribuables à l'apport du sel routier et de nutriments par ruissellement, avec le pourcentage des terres du bassin versant qui sont urbanisés (résidentielles ou urbaines) dans le cas de l'augmentation des chlorures ou alors développées (régions métropolitaines) ou exploitées pour l'agriculture (zones agricoles) dans le cas de l'augmentation des nutriments. Dans les régions forestières du nord-est du Minnesota, la qualité des eaux des lacs a peu varié depuis 1800. Les quelques changements observés dans cette région sont vraisemblablement reliés aux variations naturelles du climat ou des sols du bassin versant.
\end{abstract}

[Traduit par la Rédaction]

\section{Introduction}

Human activities can have profound effects on lake ecosystems. These impacts have been widely documented in a number of limnological (Edmondson and Lehman 1981; Lewis et al. 1984; Jassby et al. 1995) and paleolimnological (Engstrom et al. 1985; Fritz et al. 1993; Hall and Smol 1996) studies of individual lakes or small clusters of lakes, as well as in a limited number of larger-scale studies that address regional trends in water quality. These large regional studies were undertaken to evaluate lake acidification (Kingston et al. 1990; Cumming et al. 1992), forestry practices in western Canada (Laird and Cumming 2001), or limnological change in the eastern United States attributable to multiple environmental stressors, including diverse human activities (Rohm et al. 1995; Dixit et al. 1999; Siver et al.

Received 8 January 2003. Accepted 19 December 2003. Published on the NRC Research Press Web site at http://cjfas.nrc.ca on 18 May 2004.

J17276

J.M. Ramstack. ${ }^{1,2}$ Department of Earth and Environmental Sciences, Lehigh University, Bethlehem, PA 18015, U.S.A.

S.C. Fritz. Department of Geosciences and School of Biological Sciences, University of Nebraska, Lincoln, NE 68588-0340,

U.S.A.

D.R. Engstrom. St. Croix Watershed Research Station, Science Museum of Minnesota, Marine on St. Croix, MN 55047, U.S.A.

${ }^{1}$ Corresponding author (e-mail: jramstack@mbl.edu).

${ }^{2}$ Present address: Boston University Marine Program, Marine Biological Laboratory, Woods Hole, MA 02543, U.S.A. 
1999). Little synoptic work has been undertaken in central North America, where widespread agricultural and forestry practices, as well as mining, may have had significant impacts on aquatic ecosystems.

Minnesota is geographically diverse, and different parts of the state vary in their history of settlement and land use. Pollution is a problem in many of Minnesota's aquatic ecosystems as a result of runoff from agriculture and urban development in the southern part of the state, as well as atmospheric transport of pollutants throughout the region (Swain et al. 1992). Paleolimnological studies have been used previously to reconstruct human impact on regional lakes (Bradbury 1975; Bradbury and Winter 1976; Brugam and Speziale 1983); however, these earlier studies involved qualitative, not quantitative (Charles and Smol 1994), assessments of trophic change and included only a small selection of lakes. Moreover, strong environmental gradients characterize the state, and short-term shifts in climate have the potential to affect lake systems and hence water quality (e.g., Schindler et al. 1996; Bradbury et al. 2002). Hence, it is important to evaluate human-induced limnological change against a background of natural environmental variability.

Only a very small number of regional paleolimnological studies have analyzed multiple lakes and multiple time intervals in evaluating human impacts on lacustrine systems (Cumming et al. 1994; Laird and Cumming 2001). The majority have compared a single sample from presettlement times with modern conditions and assumed that the observed change is largely a result of human modification of the environment. However, it is difficult to disentangle the impact of natural environmental variability from impacts attributable directly to humans based on a simple comparison of two points in time. Here, we evaluate the magnitude of human impacts relative to natural forcing in a suite of 55 lakes from three different ecoregions of Minnesota variously affected by human activities. We compare the magnitude of twentieth century change with change over a 50-year period in the eighteenth century, before European settlement of the region. This comparison is based on a diatom transfer function developed from regional lakes (Ramstack et al. 2003), which is used to generate quantitative reconstructions of water chemistry conditions from sediment cores.

\section{Materials and methods}

\section{Study area}

The 55 lakes in this study occur in three of Minnesota's ecoregions (Omernik 1987): Northern Lakes and Forests (NLF), North Central Hardwood Forests (NCHF), and Western Corn Belt Plains (WCBP), as well as the Twin Cities metropolitan (Metro) region (Appendix A, Table A1; Fig. 1). These ecoregions span gradients in vegetation, precipitation, geology, and land use that run from northeast to southwest across the state. The lakes were chosen for a study on mercury deposition across Minnesota (Engstrom et al. 1999), with the addition of five lakes from agricultural regions in southern Minnesota (those in the WCBP ecoregion). The lakes were not chosen randomly for the previous study; however, they are qualitatively representative of the larger population of lakes in each of the ecoregions.
The study lakes range in size from 5.3 to 644.8 ha, although only two of the lakes (Diamond and Wilson) exceed 200 ha (Appendix A, Table A2). The range of lake surface areas is similar for the Metro and NLF groups (median area $=38$ and 47 ha, respectively) and only slightly larger for the NCHF and WCBP groups (median = 76 ha). Maximum lake depth for the entire data set ranges from 2.4 to $42.7 \mathrm{~m}$, with WCBP lakes being somewhat shallower than those in the other three groups (median $=13.1,10.5,11.4$, and $8.2 \mathrm{~m}$ for Metro, NLF, NCHF, and WCBP, respectively).

Total catchment area (excluding lake surface) for the 55 study sites ranges from 32 to 4028 ha (Appendix A, Table A2), whereas the ratio of total catchment to lake surface ranges from 1.12 to 120.8 with a median value of 5.57 and an interquartile range (IQR) of 10.74. About half of the 55 lakes receive drainage from upstream lakes within their catchments. The primary catchment, which excludes that portion of the watershed above the outflow from these lakes, ranges from 18 to 1850 ha and in most cases is less than half that of the total catchment. Additional information on the lakes can be found in Ramstack et al. (2003) and Engstrom et al. (1999).

The NLF region is dominated by mixed conifer-hardwood forest, with only small tracts of land permanently cleared for agriculture and iron mining. Urban development in this portion of the state is limited; however, some lakeshores are lined with resorts and cabins. Most lakes are small and deep and are oligotrophic to mesotrophic (Appendix A, Table A1). Soils are generally thin and overlie base-poor crystalline bedrock of the Canadian Shield. Twenty of the study lakes are in this ecoregion: five are clustered in carbonate-rich terrain near the city of Grand Rapids (lakes 21-25), five are located within Voyageurs National Park near the Canadian border (lakes 36-40), six are located within the highlands along the north shore of Lake Superior (lakes 26-31), and the remaining four are scattered widely across the Superior National Forest (lakes 32-35) (Fig. 1).

The NCHF ecoregion is characterized by a mosaic of land uses (Heiskary et al. 1987). Agricultural and forested use predominates in the west-central portion of the ecoregion, whereas the Metro area in the east is dominated by urban, wetland, and forested areas (Engstrom et al. 1999). The lakes in this region range from oligotrophic to hypereutrophic (Appendix A, Table A1). In contrast with the NLF region, most of these lakes lie in calcareous glacial drift and consequently have high alkalinities. Forty-four percent of the lakes in this ecoregion are considered unsuitable for contact recreation because of low water quality (Minnesota Pollution Control Agency 2000). Annual evaporation generally exceeds precipitation, and lake levels often fluctuate seasonally and from year to year. Ten of the study lakes are located within this region, and half of these have large, agriculturally dominated watersheds and low water quality. The other five lakes are situated in smaller and more forested catchments and have higher water quality. All but two of the lakes are ringed by summer cottages and year-round homes.

The Metro region is considered part of the NCHF ecoregion but is treated separately here, as many of the lakes are affected by urban land use. Twenty of the study lakes are in this metropolitan area, and approximately half are in urban or residential neighborhoods (within $10 \mathrm{~km}$ of the center of 
Fig. 1. Location of the 55 study lakes along with the ecoregions of Minnesota, U.S.A. (modified from Tester 1995). See Appendix A for key to lake numbers.

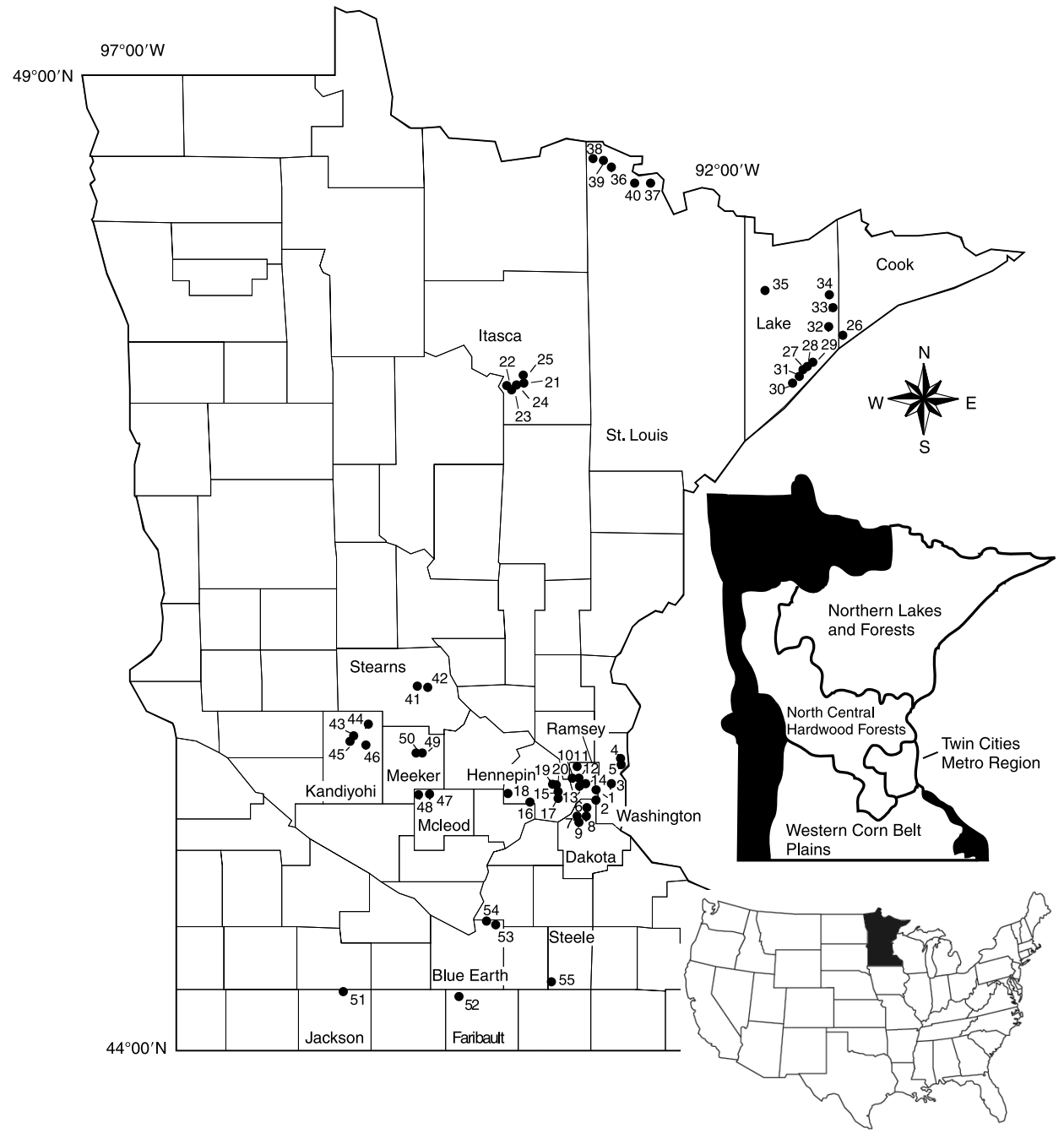

either Minneapolis or St. Paul). The other half is in more rural settings with a mixture of current land use, including woodlands, farms, and suburban development.

Agriculture is the primary land use in the WCBP ecoregion, and more than $80 \%$ of the land is under cultivation. The five study lakes in this region are large and shallow. As a result of rich soils, shallow lake basins, and runoff from farm fields, most lakes in this region are classified as eutrophic or hypereutrophic (Appendix A, Table A1).

\section{Geographic information system (GIS) database}

The GIS database for this study contains seven thematic layers in Arc/Info format for each of the 55 watersheds. Each layer is cast in the Universal Transverse Mercator Zone 15 projection with units in metres, the North American Datum 1983 for horizontal reference, and the Global Reference System 1980 as the selected spheroid. Watershed boundaries were initially delineated on U.S. Geological Survey 7.5minute series topographic quadrangles for each of the study lakes digitized in ArcEdit to form the Basemap cover. The source data for the Transportation cover is the State of Minnesota BaseMap developed by the Minnesota Department of
Transportation. The land cover layer contains polygons representing 10 land-use types (grassland, agland, brushland, deciduous forest, conifer forest, mixed forest, open water, wetlands, built up, and clearcut), based on a modified U.S. Geological Survey classification scheme (Anderson et al. 1976). These features were interpreted from early-spring 1991-1992 color infrared National Aerial Photography Program photographs. Stereoscopic interpretations were accomplished using an Old Delft scanning stereoscope with a 4.5 magnification setting resulting in an image scale of about 1:9000. Landscape feature classes were digitized using ArcEdit and a U.S. Geological Survey panchromatic digital orthophoto quarter quad as a background image. Approximately $50 \%$ of the watersheds in the study were spot field checked for classification accuracy.

\section{Sediment cores, water chemistry analysis, and sample preparation}

Sediment cores were obtained in the mid-1990s in conjunction with a study of mercury deposition in Minnesota (Engstrom et al. 1999). The cores were taken with a piston corer from a deep flat region of each of the lake basins. The 
cores were sectioned in the field and subsequently freeze dried. A chronology was established with ${ }^{210} \mathrm{~Pb}$ dating using the constant rate of supply model (Appleby and Oldfield 1978). Based on the ${ }^{210} \mathrm{~Pb}$ chronology and extrapolated sedimentation rates (Engstrom et al. 1999), samples of 1-5 cm in thickness and representing 2-4 years of accumulation were taken from the core top and from the intervals representing approximately 1750,1800 , and 1970 .

In the modern samples, at least 400 diatom valves were counted along transects. Three hundred valves were counted in the core sections, or 10 transects, whichever occurred earlier. Krammer and Lange-Bertalot (1986-1991) and Patrick and Reimer (1966) were used to identify diatoms to species. Reconstructions were not performed on seven core samples because of low diatom concentration.

A modern diatom calibration data set developed for Minnesota lakes (Ramstack et al. 2003) was used to reconstruct water chemistry characteristics from sedimentary diatom assemblages. Weighted averaging calibration, with inverse deshrinking (Juggins and ter Braak 1992), was used to generate a transfer function to infer chloride $(\mathrm{Cl})$, color, total phosphorus (TP), and $\mathrm{pH}$ from sedimentary assemblages. Each of these variables had a statistically significant influence $(p<0.005)$ on modern diatom distribution in the calibration data set. The strength of the transfer function is reported in terms of the squared correlation $\left(r^{2}\right)$ and the root mean square error (RMSE) (Table 1). Because the same data are used to generate the model and test it, the RMSE usually underestimates the RMSE of prediction (RMSEP), and the validation step of jackknifing is used. For each lake, the transfer function was applied to a surface sediment sample representing modern (1995) conditions, a subrecent interval (approximately 1970), and the 1800 and 1750 core sections. See Ramstack et al. (2003) for additional details on the transfer function development and statistical analyses.

\section{Results}

\section{Core diatom assemblages}

Presettlement sediments from sites along the North Shore of Lake Superior (NLF ecoregion) are dominated by Aulacoseira ambigua (Grunow) Simonsen and Cyclotella pseudostelligera Hustedt (Fig. 2), species that are characteristic of oligotrophic to mesotrophic lakes (Hall and Smol 1992; Reavie et al. 1995b). In some recent samples (1995 and 1970) from this region, Fragilaria construens var. venter (Ehrenberg) Grunow and Asterionella formosa Hassall show small increases relative to Aulacoseira ambigua. Lakes in Voyageurs National Park, as well as the Superior National Forest, are dominated in both recent and presettlement samples by Asterionella formosa, Cyclotella stelligera Cleve and Grunow, and Tabellaria flocculosa (Roth) Kützing; these diatoms have TP optima that are characteristic of mesotrophic systems (Hall and Smol 1992; Reavie et al. 1995a, 1995b). However, Cyclotella stelligera is much less common in the down-core sections than late twentieth century sections. Fragilaria crotonensis Kitton, which has been associated with nutrient enrichment in lakes of low to moderate alkalinity (Bradbury 1975; Brugam 1979), is dominant in presettlement core sections from two of the five lakes clustered near Grand Rapids, as compared with four lakes in the mod-
Table 1. Results of the weighted averaging regression.

\begin{tabular}{llll}
\hline $\begin{array}{l}\text { Environmental } \\
\text { variable }\end{array}$ & $r^{2}$ & $\begin{array}{l}\text { RMSE } \\
\text { (apparent) }\end{array}$ & $\begin{array}{l}\text { RMSE of } \\
\text { prediction }\end{array}$ \\
\hline $\log \mathrm{Cl}$ & 0.77 & 0.43 & 0.55 \\
$\log$ color & 0.68 & 0.20 & 0.28 \\
$\log \mathrm{TP}$ & 0.68 & 0.19 & 0.25 \\
$\mathrm{pH}$ & 0.80 & 0.28 & 0.35 \\
\hline
\end{tabular}

Note: The strength of the transfer function is reported in terms of the squared correlation $\left(r^{2}\right)$, the root mean square error (RMSE) (observed - inferred), and the jackknifing root mean square error (RMSE of prediction) (modified from Ramstack et al. 2003)

ern samples. Stephanodiscus minutulus (Kützing) Cleve and Möller makes up $21 \%$ of the diatom assemblage in the 1800 core section from one of these five lakes (Loon) and $10 \%$ of the 1750 core section of another (Long). These are the only two samples from the NLF ecoregion in which Stephanodiscus is a significant portion of the diatom assemblage.

In the 11 centrally located lakes of the Metro region (all now highly urbanized), small Stephanodiscus species, which are known to have high $\mathrm{P}$ requirements (Bradbury 1975; Fritz et al. 1993; Bennion et al. 1996), are much less prevalent in presettlement sediments than in the recent samples (Fig. 2). In the presettlement core sections, the species assemblages are dominated by Aulacoseira ambigua, Cyclotella bodanica var. lemanica (O. Müller) Bachmann, and Cyclotella michiganiana Skvortzow. In the nine lakes more distant from the urban core, presettlement species assemblages are dominated by Aulacoseira ambigua, Fragilaria brevistriata Grunow, and Fragilaria construens var. venter, whereas Asterionella formosa, Fragilaria crotonensis, and Cyclotella bodanica var. lemanica are more abundant in recent samples.

In what is now the agricultural part of Minnesota, some of the lakes contain presettlement diatom assemblages similar to those of the present day, whereas others are substantially different (Fig. 2). The 1800 and 1750 core sections of lakes in the WCBP ecoregion are dominated by Aulacoseira ambigua, Aulacoseira granulata (Ehrenberg) Simonsen, and small Stephanodiscus species. The present-day assemblages are similar; however, in a few of the lakes, there are larger percentages of mesotrophic and eutrophic planktonic taxa, including Asterionella formosa, Fragilaria crotonensis, and small Stephanodiscus species in the recent samples, with small declines in benthic Fragilaria species. Lakes in the currently agricultural areas of the NCHF ecoregion are dominated in presettlement times by small Stephanodiscus species, Fragilaria construens var. venter, and Fragilaria pinnata Ehrenberg. The recent samples are dominated by small Stephanodiscus species, Aulacoseira granulata, and Aulacoseira ambigua. In contrast, in currently forested parts of this ecoregion, Fragilaria construens var. venter is present in 1800 and 1750 core sections from the majority of the lakes. Other common diatoms in presettlement levels include Cyclotella bodanica var. lemanica, Aulacoseira ambigua, and Aulacoseira granulata. In the modern samples, Fragilaria crotonensis and small Stephanodiscus species dominate. 


\section{Water chemistry reconstructions}

Reconstructions were made for $\mathrm{Cl}, \mathrm{pH}$, color, and TP. The results for the pre- versus post-settlement diatom reconstructions are expressed as the change from 1800 to the present (1995) (Fig. 3), and change before European settlement is expressed as the change from 1750 to 1800 (Fig. 4). For Cl, color, and TP, the reconstructions are based on logtransformed modern water chemistry data. Thus, the changes shown are $\log$ minus $\log$ values, which are expressions of the ratio of change. The RMSEP is used to evaluate the magnitude of water chemistry change. In our discussion of reconstructed water chemistry trends below, we use the term "significant" not in the strict statistical sense but for changes between two periods of time that exceed the RMSEP. Regional water chemistry means are compared for the 1750, 1800, 1970, and modern core sections (Fig. 5) (NCHF and WCBP lakes are grouped together because of the similar surficial geology and strong agricultural influence in both regions; variables that were $\log$ transformed $(\mathrm{Cl}$, color, and TP) are expressed as back-transformed values).

All of the Metro region lakes show increases in $\mathrm{Cl}$ concentrations from 1800 to the present (10 of which exceed the RMSEP). The mean concentration has increased from 6 to $47 \mathrm{ppm}$, and the range of values has increased considerably (Fig. 5). In the NCHF and WCBP ecoregions, four lakes also show an increase in $\mathrm{Cl}$ that exceeds the RMSEP, whereas only one lake records a decrease. Overall, the median value for the region has risen. Three lakes in the NLF ecoregion record a significant decrease in $\mathrm{Cl}$.

Lakes in the NLF ecoregion show either a decrease in $\mathrm{pH}$ (3 sites) or no significant change since 1800 (Fig. 3). In the other regions, the majority of lakes record an increase in $\mathrm{pH}$, and only two lakes show a decrease that exceeds the RMSEP (Fig. 3). Only eight of the study lakes show a change in color since 1800. Regional trends in this variable are not apparent (Fig. 3), although no lakes in the NLF ecoregion show a significant decrease in color.

TP shows strong regional patterns (Figs. 3 and 5). Of the 20 Metro region lakes, 12 show increases in diatom-inferred TP between 1800 and today (six exceed the RMSEP); none of the lakes in this region show a significant decrease (Fig. 3). The average TP concentration for this group of lakes has increased from 23 to $35 \mathrm{ppb}$ since settlement, whereas the range of values has doubled (Fig. 4). Half of the 15 lakes in agricultural areas of west-central and southern Minnesota show increases in TP from 1800 to the present (three of which exceed the RMSEP); the rest have not shown significant change (Fig. 3). In contrast, the northeastern lakes show no systematic TP changes from 1800 to the present; about half the lakes show modest declines in TP, whereas the others show modest increases or no change (Fig. 3). It is also clear from the diatom reconstructions that TP levels in southern and western Minnesota, although currently enhanced by human impacts, have always been higher than those in the northeastern part of the state (Fig. 5).

\section{Land use and water quality change}

GIS characterization of catchment land use for the 55 study lakes follows closely the general pattern for these ecoregions as a whole. The primary catchments of the Metro lakes are dominated by built-up cover types (residential and commercial), those in the NLF by forest (conifer and deciduous), and catchments in the NCHF and WCBP by agriculture (pasture and tillage) (Appendix A, Table A2). The median for built up in Metro catchments is $78 \%$, with only two lakes (Schultz and Little Long) having less than $20 \%$ of this cover type. By contrast, 14 of the NLF lakes have catchments that are entirely undeveloped (forest or wetland), and five more are more than $80 \%$ undeveloped. Among the NCHF and WCBP lakes, 10 catchments exceed 50\% agricultural land use and four others have more than $20 \%$ of this cover (Appendix A, Table A2). In the Metro area, only three lakes (Elmo, Little Carnelian, and Square, all in Washington County) have greater than $20 \%$ of their catchments in agriculture, although most lands in the Metro region were intensively farmed at one time.

Diatom-inferred water quality changes between 1800 and the present (numerically represented as the difference between present-day and 1800 values, log transformed except $\mathrm{pH})$ are correlated with catchment land-use patterns within ecoregions (Table 2). Reported correlations are based on primary catchment land use (which excludes areas above the outflow from upstream lakes), although results for total catchment land use are quite similar. Among Metro region lakes, increases in TP show significant positive relationships with the percentage of catchment area devoted to built-up cover types $(r=0.54, p=0.01)$ and road surfaces $(r=0.49$, $p=0.03$ ). Chloride increases are even more strongly correlated with these cover types (built up, $r=0.71, p<0.01$; roads, $r=0.63, p<0.01$ ). Because built-up areas have more road surfaces, these cover types are highly correlated, and their individual influences on TP and $\mathrm{Cl}$ increases cannot be disentangled. Nonetheless, these relationships strongly imply that the magnitude of postsettlement water quality change ( $\mathrm{TP}$ and $\mathrm{Cl}$ ) in the Metro region is directly related to the degree of urbanization within individual lake catchments.

Among lakes in the NCHF ecoregion, TP increases are positively correlated with the percentage of catchment devoted to agriculture $(r=0.72, p=0.02)$ and conversely with the percentage of catchment remaining in forest cover $(r=$ $-0.62, p=0.06$ ) (Table 2). Postsettlement increases in apparent color (dissolved organic carbon (DOC)) are also related to agricultural land use $(p=0.68, p=0.03)$. These results provide strong evidence that conversion to agricultural land uses has caused proportional increases in nutrient runoff and historical eutrophication of NCHF lakes. The increases in lake color, although unexpected, may be related to increased export of soil organic matter (possibly enhanced by field application of livestock manure) from catchment areas devoted to tillage agriculture.

In the small group of lakes $(n=5)$ from the WCBP ecoregion, TP increases are most strongly correlated (although not significantly because of the small sample size) with the percentage of catchment in built-up land uses, primarily lakeshore cottages and homes $(r=0.63, p=0.3)$. The weak correlation with agricultural land use (as compared with NCHF lakes) results from the fact that all WCBP catchments are dominated by agriculture (60-90\%).

Among the NLF lakes of northeastern Minnesota, diatom reconstructions reveal little if any changes in postsettlement water quality and only weak correlations with present-day catchment land use (Table 2). These catchments remain al- 
Fig. 2. Diatom relative abundance of the most common taxa in the four analyzed core samples, arranged according to ecoregion. Presettlement samples are indicated with open bars and the postsettlement pair of samples $(1970,1995)$ are indicated with solid bars. For each lake, the four dates are arranged in order from oldest at the base to most recent at the top.

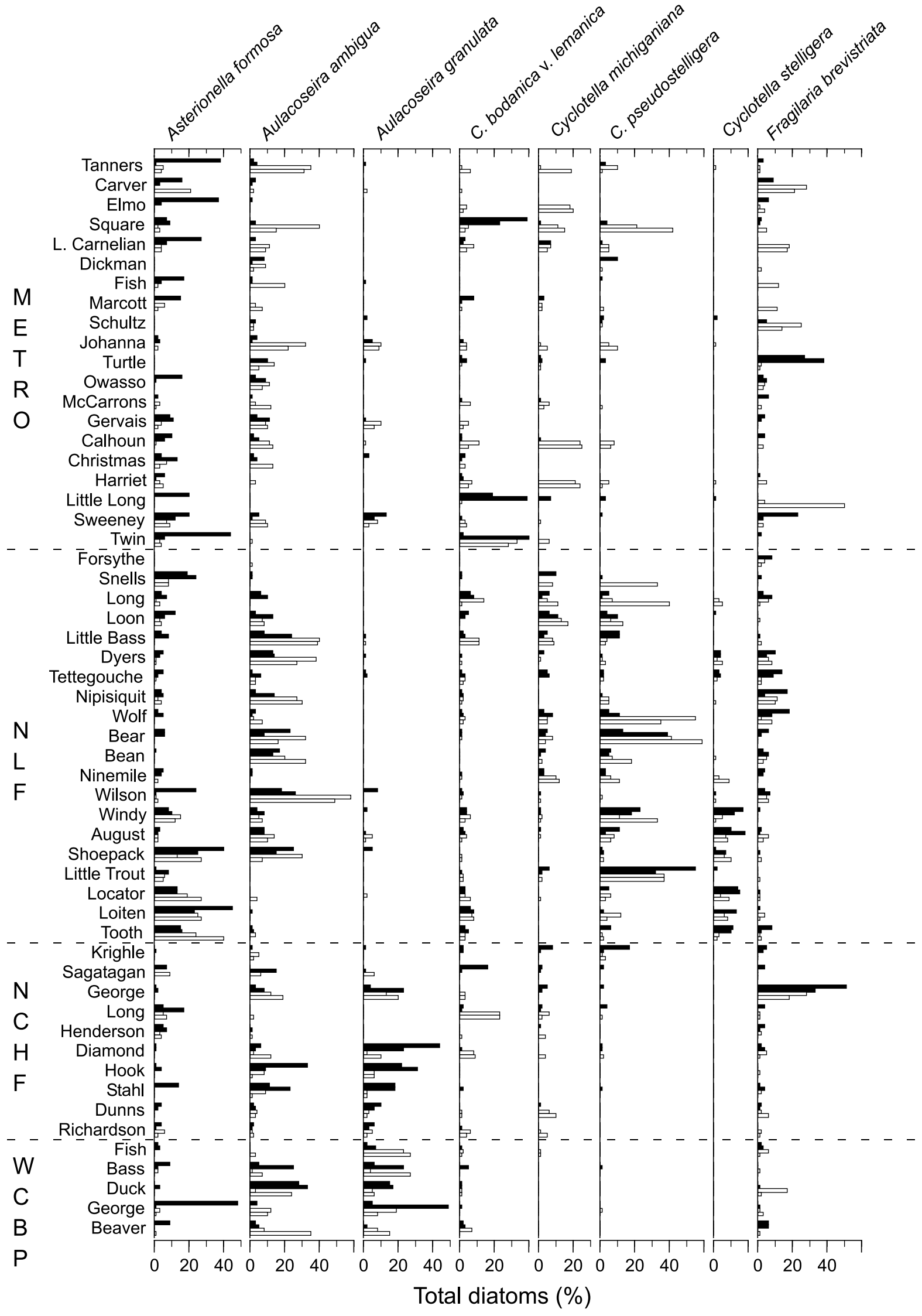


Fig. 2 (concluded).

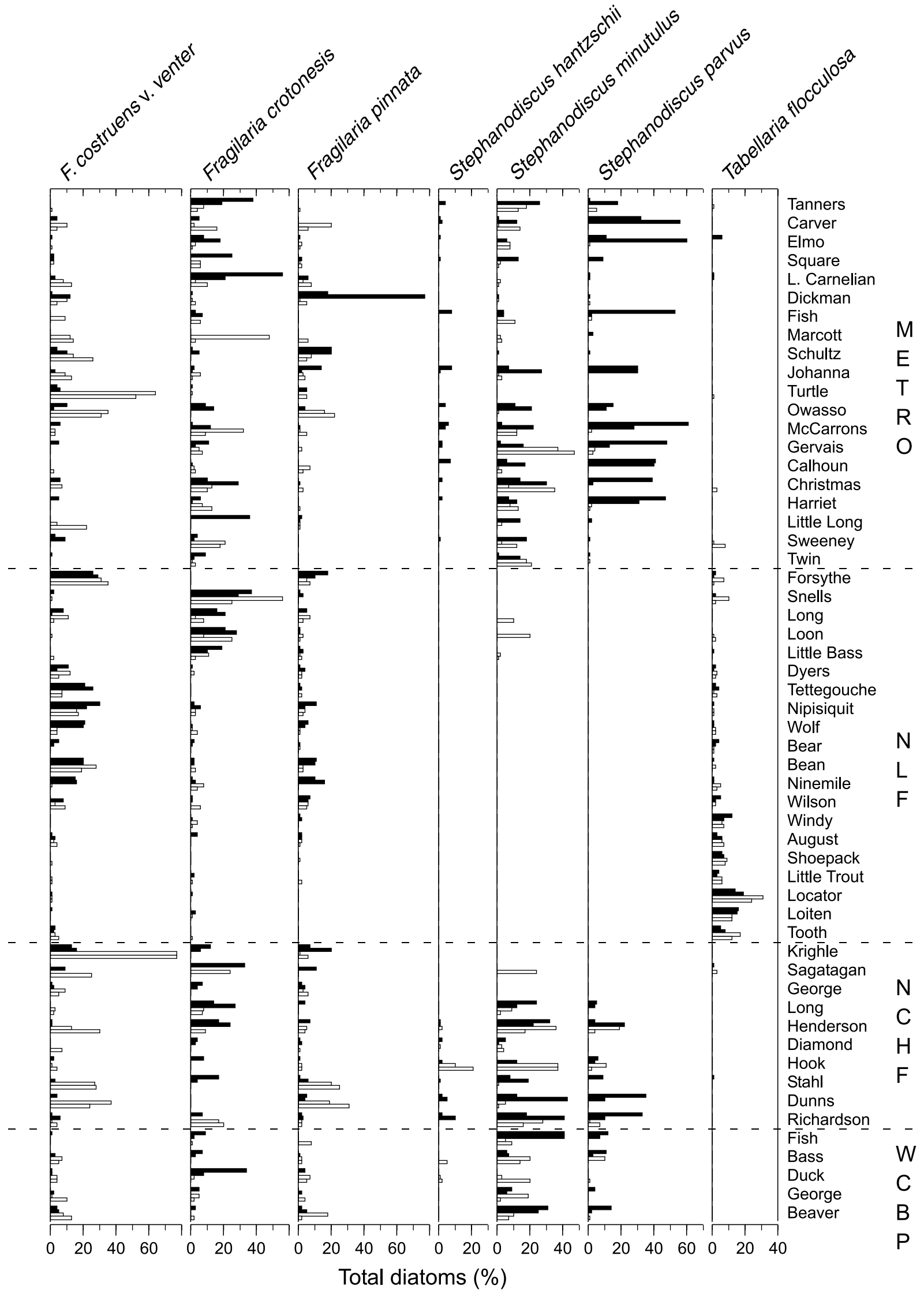


Fig. 3. Diatom-based reconstruction of $\log \mathrm{Cl}, \mathrm{pH}, \log$ color, and $\log \mathrm{TP}$ for 52 of the study lakes. The lakes are grouped by ecoregion, and the results are expressed as the change from 1800 to the present. The lines represent \pm RMSEP. Asterisks indicate a change greater than the RMSEP.
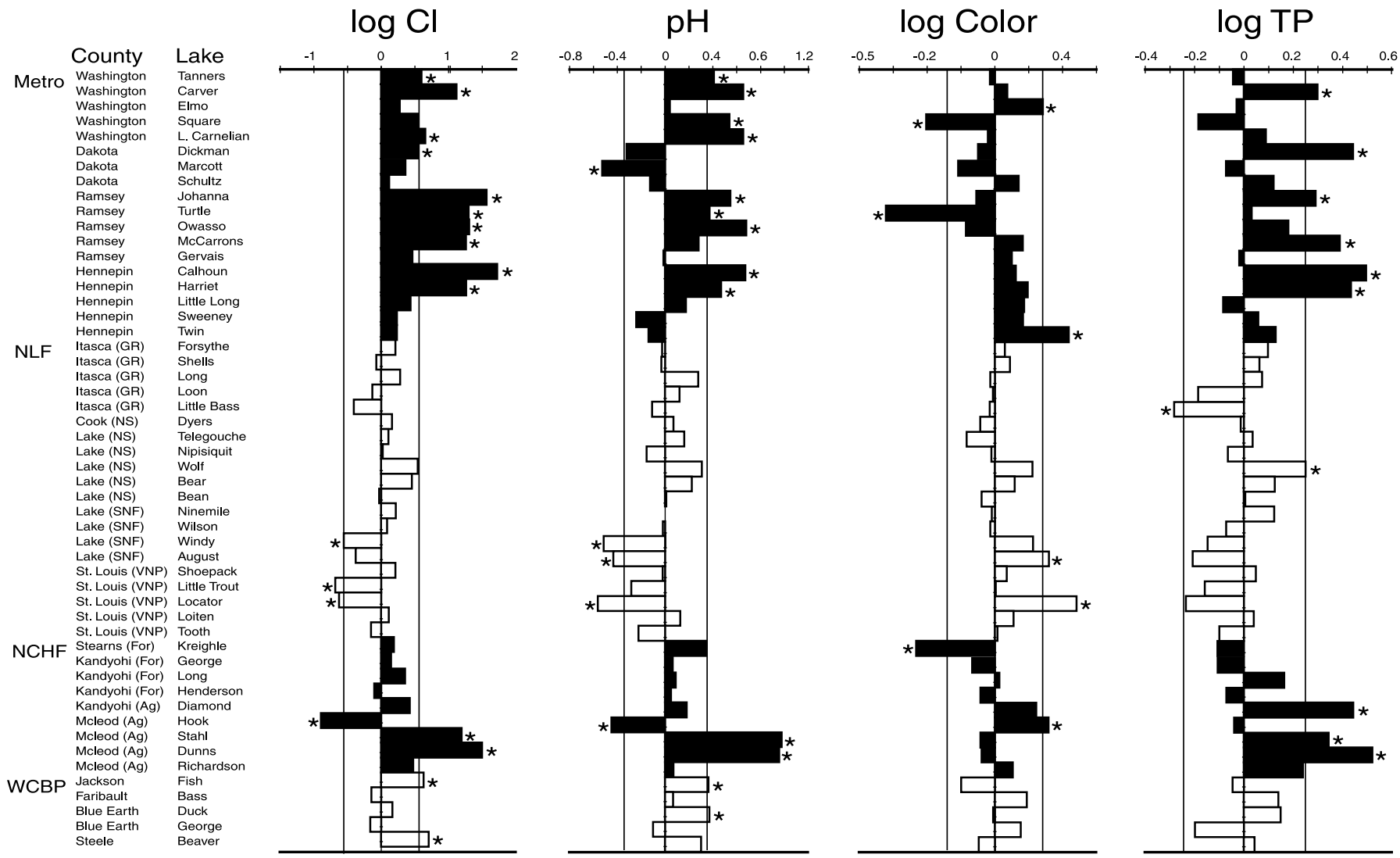

most entirely in an undeveloped state (forest and wetland cover types), and although some have been logged historically (and a few partially farmed), the absence of significant land-use conversion is clearly reflected in the absence of water quality change.

Post-1800 water quality changes also appear to be influenced by geomorphic characteristics of the lakes. In the Metro region, $\mathrm{Cl}$ and $\mathrm{pH}$ increases were greater in larger (surface area) lakes ( $r=0.59$ and 0.56 , respectively), which is likely related to the fact that only the smaller lakes in this group retain undeveloped (forested) catchments (Table 2). Among NCHF lakes, those with larger catchment to lake area ratios showed greater increases in TP $(r=0.67, r=$ $0.03)$ and $\mathrm{Cl}(r=0.63, r=0.05)$, presumably because larger catchments are more agricultural than smaller ones among this group of lakes $(r=0.64)$. In the WCBP, shallower lakes showed larger TP increases $(r=-0.72)$, whereas larger lakes with larger catchments and larger catchment to lake area ratios showed greater increases in $\mathrm{pH}(r=0.65-0.69)$; because of small sample size, none of these relationships are significant. Finally, among the relatively pristine NLF lakes, $\mathrm{pH}$ changes are negatively correlated with total catchment area $(r=-0.60, p=0.04)$. Lakes with smaller catchments tend to be dominated by direct precipitation and have lower buffering capacity and hence may be more susceptible to $\mathrm{pH}$ depression from acid rain. Present-day $\mathrm{pH}$ and catchment area are correlated $(r=0.44, p=0.05)$ among NLF lakes.

\section{Natural variability}

Before 1800, Minnesota had not been settled by Europeans; hence, the anthropogenic influence on lake systems was likely extremely low. Therefore, the difference in water chemistry between 1750 and 1800 is a measure of natural variability. This natural variability is expressed as the change from 1750 to 1800 , in $\log$ units (Fig. 4), and the regional water chemistry means for these two periods are also compared (Fig. 5). Among the lakes, only two show a change in $\mathrm{Cl}$ that exceeds the RMSEP over the 50-year period between 1750 and 1800; lakes in the NLF ecoregion show the least amount of change in $\mathrm{Cl}$ concentration (Fig. 4). Only six of the study lakes show a significant change in $\mathrm{pH}$ over this time, and there are no clear regional trends. Only one lake records a significant shift in color, and there do not appear to be any regional trends in this variable. Similarly, there are no clear regional trends in $\mathrm{TP}$, and only one lake shows a significant change. In terms of nutrient concentrations, the presettlement range of values for both the Metro and NLF lakes is quite small, in contrast with those in the NCHF and WCBP ecoregions (Fig. 5).

\section{Discussion}

The natural environmental gradients that characterize Minnesota are reflected in the diatom assemblages of the individual ecoregions as differences in relative abundances 
Fig. 4. Diatom-based reconstructions of water quality variables expressed as the change from 1750 to 1800 . The lines represent \pm RMSEP. Asterisks indicate a change greater than the RMSEP.

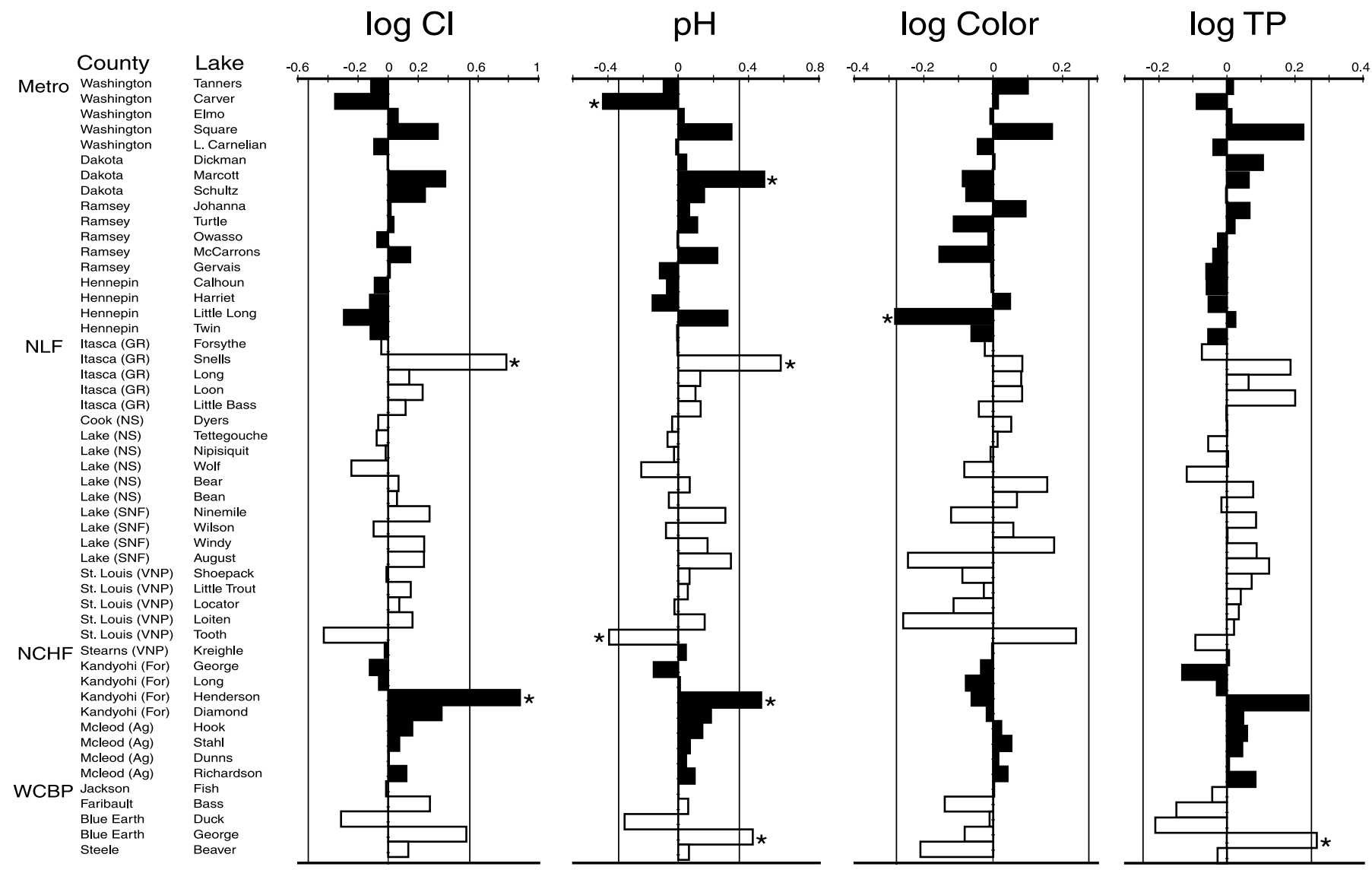

among a suite of about a dozen planktonic taxa. The majority of these taxa are found in lakes throughout the state, albeit in varied proportions; however, several species are more restricted in their distribution. These include Aulacoseira granulate in the south-central and southwestern part of the region, Tabellaria flocculosa and Cyclotella stelligera in the NLF region in the northeast, and small Stephanodiscus species, which are widespread except in the NLF. Human impacts have not only changed the relative abundance of individual taxa within an ecoregion but in some cases have reduced or nearly eliminated some taxa and expanded the range of others. Thus, Cyclotella michiganiana and Cyclotella pseudostelligera, which were abundant in the Metro region before settlement, are now largely absent and Stephanodiscus hantzschii Grunow $S$. parvus Stoermer \& Håkansson has expanded. These floristic changes, which are particularly large in the Metro region, are reflected in the reconstructed water chemistry values for $\mathrm{Cl}, \mathrm{P}$, and to some extent $\mathrm{pH}$ and color.

Chloride is a conservative ion, and changes in concentration can result from evaporative concentration or dilution driven by differences in precipitation relative to evaporation. However, an increase in $\mathrm{Cl}$ also can occur because of the seepage of road salts into lake basins. Little natural variation in $\mathrm{Cl}$ occurs in these Minnesota lakes over this time scale, particularly for the NLF and Metro regions. In the NLF ecoregion, precipitation exceeds evaporation, and thus the lakes are not very affected by evaporative concentration. In contrast, in the agricultural ecoregions of NCHF and WCBP, where on average precipitation is lower and evaporation is higher, evaporative enrichment between 1750 and 1800 may have increased ionic concentration. Although these increases are not individually significant, the trend for the group as a whole is (paired $t$ test, $t=2.16, p<0.05$ ). Since European settlement, however, prominent and statistically significant changes are evident. All of the lakes in the Metro region, and some in the agricultural regions, have recorded an increase in $\mathrm{Cl}$. The average $\mathrm{Cl}$ value for the metro group of lakes has risen by an order of magnitude, a change that is highly significant (paired $t$ test, $t=7.03, p<0.0001$ ). It seems likely that this strong directional signal between the modern and presettlement conditions is a result of the seepage of road salts into the lakes and possibly leakage from septic systems in outlying areas. Increased concentrations of road salts have also been observed in lakes in some parts of the northeastern United States (Dixit et al. 1999; Siver et al. 1999).

Regional trends in $\mathrm{pH}$ do occur, although they are less distinct than for some other variables. The majority of decreases in $\mathrm{pH}$ since settlement are in the NLF ecoregion. These lakes have a low buffering capacity, making them susceptible to acidification by acid rain; however, only three lakes showed a significant decrease in $\mathrm{pH}$ since settlement. These results are consistent with conclusions from the 
Fig. 5. Distribution by ecoregion of the reconstructed variables for 1750, 1800, 1970, and 1995 (modern) core sections. Variables that were log transformed $(\mathrm{Cl}$, color, and TP) are expressed as back-transformed values. Boxes represent interquartile ranges, bars delineate upper and lower $10 \%$, and the center line is the median. Means are shown by solid squares.
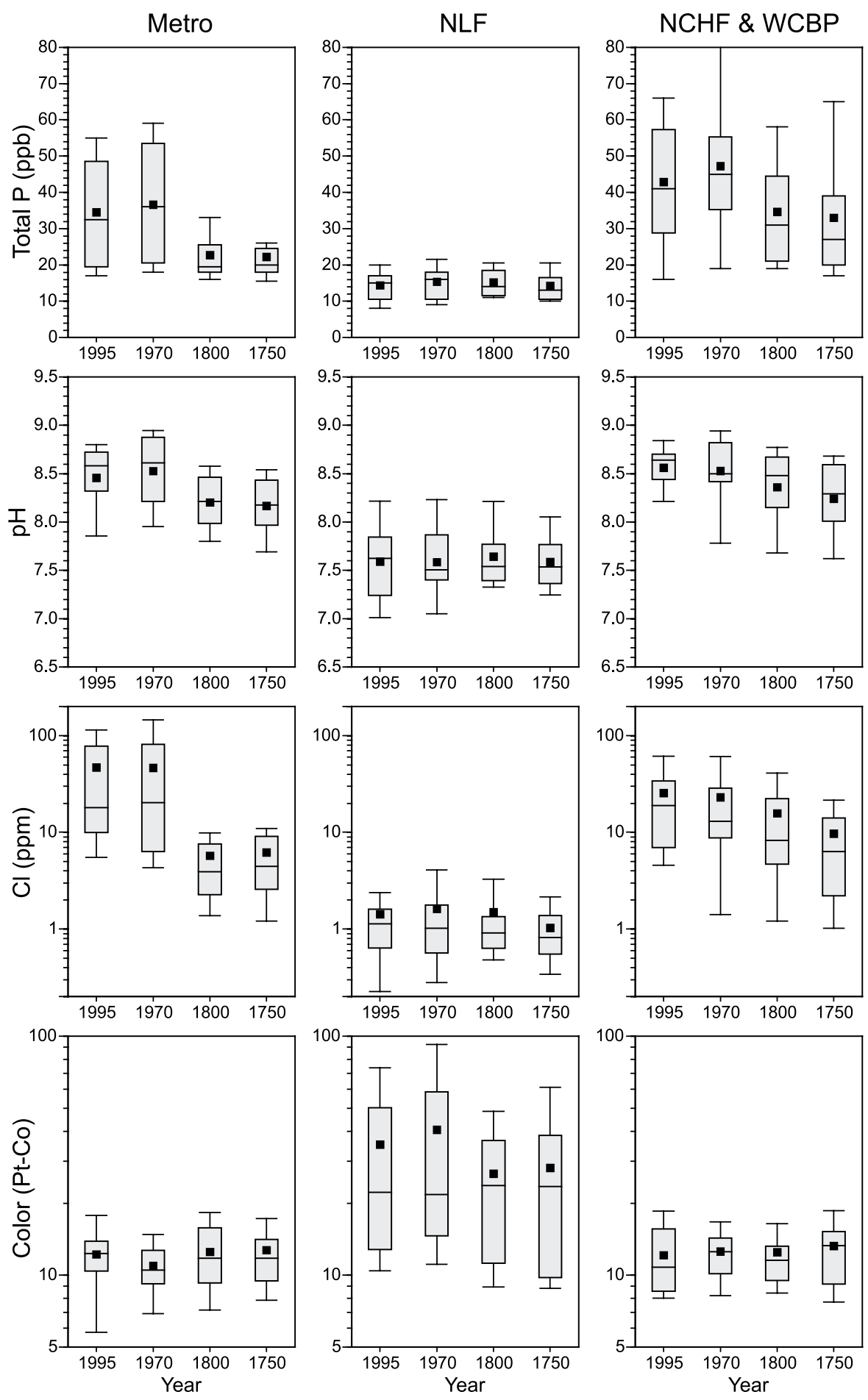

PIRLA project (Paleoecological Investigation of Recent Lake Acidification; Kingston et al. 1990), which included three lakes from the NLF ecoregion and found changes in diatom-inferred $\mathrm{pH}$ since 1860 of less than $0.2 \mathrm{pH}$ unit. The one lake in this region that records a significant increase in $\mathrm{pH}$ between 1750 and 1800 is situated in more carbonaterich terrain near the city of Grand Rapids. Increases in $\mathrm{pH}$ exceed the RMSEP in nine Metro region lakes and four agricultural region lakes, although the overall change for each region is not statistically significant (paired $t$ test, $p=0.06$ and 0.15 , respectively). These $\mathrm{pH}$ increases probably reflect higher levels of algal productivity (caused by nutrient enrichment), which can raise $\mathrm{pH}$ by photosynthetic uptake of $\mathrm{CO}_{2}$ (Hodell et al. 1998). 
Changes in water color (DOC) can result from changes in vegetation and soils (Schindler et al. 1996; Williamson et al. 1999) or photobleaching of DOC (Osburn et al. 2001), induced by either natural or anthropogenic factors. Only eight lakes have changed significantly in color since 1800 . The largest postsettlement changes are in the NLF ecoregion, where the coniferous vegetation and peaty soils contribute to regionally high DOC levels. However, the apparent increase in mean regional water color (1800 to the present) is not regionally significant (paired $t$ test, $t=1.83, p=0.8$ ), and a similar variability in water color is apparent between 1750 and 1800 . Such results imply that modern land-use practices are not significantly altering the DOC content of these lakes and that the majority of change is a result of natural variation in vegetation and climate.

Natural changes in vegetation, soils, and climate can alter nutrient concentrations in lakes (Fritz 1996; Kilham et al. 1996), as can a variety of anthropogenic activities. Only one lake shows a significant change in TP between 1750 and 1800 , and no regional trends are apparent. However, very clear trends occur from presettlement to the present, in terms of both mean TP concentrations and the range of variation. There is no directional change in TP since 1800 in the NLF ecoregion, but large increases (exceeding the RMSEP) occur in the other ecoregions. The increase in TP is highly significant in the Metro group of lakes (paired $t$ test, $t=3.39, p<$ 0.01 ) but not so in the agricultural regions (NCHF and WCBP combined: paired $t$ test, $t=1.29, p=0.22$ ). The clear trends among ecoregions since settlement (and the lack of those trends from 1750 to 1800) are a strong indication that modern land-use practices have had significant effects on the trophic status of these aquatic systems. Although the NLF ecoregion is the most pristine in this study, there are local impacts such as cottaging (Hall and Smol 1996) and logging, both historic and recent (Fritz et al. 1993), that have the potential to increase P loading to these systems. However, these influences appear to have been relatively minor on average, as there has been very little change in the TP levels of NLF lakes since European settlement.

A noticeable increase in small Stephanodiscus species that have high P optima (Bradbury 1975; Fritz et al. 1993; Bennion et al. 1996) occurs in the postsettlement core sections of most Metro region lakes. Although many of these lakes have been the targets of cleanup efforts over the past few decades, most are more nutrient rich today than before settlement. Nonetheless, of the six lakes in the Metro region that show increases in TP since 1800 that exceed the RMSEP (and would be classified today as eutrophic to hypereutrophic), three of these were eutrophic in 1800, based on these reconstructions. This is not to say that cleanup efforts should not continue, but an awareness of baseline conditions for these lakes could be used to better inform management goals for restoration.

By reconstructing water chemistry conditions before $\mathrm{Eu}-$ ropean settlement in a suite of lakes in regions with different land-use histories, it is possible to begin to evaluate the amount of change that can be attributed to anthropogenic influences. These data also contribute to an understanding of to what degree the changes reflect natural variability and how much and what types of change are actually related to current land-use practices. Overall, it seems that increases in 
$\mathrm{Cl}$ and TP in the urban and agricultural regions have been primarily due to human impacts via the seepage of road salts into lake basins and the runoff of nutrients from agricultural and urbanized areas. Indeed, increases in $\mathrm{Cl}$ (from presettlement to modern) in Metro region lakes are most strongly correlated with the percentage of watershed area devoted to residential or commercial land use $(r=0.71)$ and road surfaces $(r=0.63)$, whereas TP increases show significant correlation with the percentage of watershed area presently in built-up (residential or commercial) land use ( $r=$ $0.54)$. Likewise, TP increases among non-Metro lakes of the NCHF are most strongly correlated with the proportion of watershed devoted to agriculture $(r=0.72)$.

The analysis of presettlement conditions allows recent limnological changes to be viewed in the context of variation over a longer period of time. Although $\mathrm{Cl}$ concentration has increased in some urban lakes since 1970 (Ramstack et al. 2003), it is clear that the largest increase predates 1970 . Similarly, although TP concentrations have changed in recent decades in lakes in both urban and agricultural areas of the state (Ramstack et al. 2003), a much larger change occurred sometime between regional settlement and 1970.

The data also suggest that in addition to changing average regional conditions, human activities also have affected the range of limnological variation. The range of presettlement variation in $\mathrm{TP}$ and $\mathrm{Cl}$ appears to be greater in agricultural parts of the state than in the lakes of the Metro region where native vegetation was originally deciduous forest. However, human impacts appear to have increased the range of variation in the urban areas of the Metro region, particularly with respect to nutrients.

In terms of changes in $\mathrm{pH}$, anthropogenic influences may be causing a decline in a small number of particularly sensitive lakes with a naturally low buffering capacity, but on a population basis, these trends are not regionally significant. An increase in $\mathrm{pH}$ is evident in some Metro region and agricultural lakes, likely the result of eutrophication. Color is the one variable measured here that does not seem to have been significantly affected by post-European land-use practices, and any fluctuations in water color since settlement appear to be due to natural changes in vegetation and soils within the watersheds.

\section{Acknowledgments}

This study was part of larger project on historical records of nonpoint source pollution that was co-directed by Edward Swain (Minnesota Pollution Control Agency). James Almendinger and Ed Swain helped with sediment coring; Steve Heiskery, Carol Hubbard and Dan Helwig assisted in limnological sampling and compilation of historic limnological data. The GIS database was constructed by Howard Post of Geodata Model Solutions. ${ }^{210} \mathrm{~Pb}$ dating and sediment handling were the responsibility of Kelly Thommes. This work was funded by the Minnesota Legislature as recommended by the Legislative Commission on Minnesota Resources through a grant to the Minnesota Pollution Control Agency.

\section{References}

Anderson, J.R., and Hardy, E.E., Roach, J.T., and Witmer, W.E. 1976. A land use and land cover classification system for use with remote sensor data. U.S. Geological Survey Professional Paper 964.

Appleby, P.G., and Oldfield, F. 1978. The calculation of lead-210 dates assuming a constant rate of supply of unsupported $210 \mathrm{~Pb}$ to the sediments. Catena, 5: 1-8.

Bennion, H., Juggins, S., and Anderson, N.J. 1996. Predicting epilimnetic phosphorus concentrations using an improved diatombased transfer function and its application to lake eutrophication management. Environ. Sci. Technol. 30: 2004-2007.

Bradbury, J.P. 1975. Diatom stratigraphy and human settlement in Minnesota. Geol. Soc. Am. Spec. Pap. No. 171.

Bradbury, J.P., and Winter, T.C. 1976. Areal distribution and stratigraphy of diatoms in the sediments of Lake Sallie, Minnesota. Ecology, 57: 1005-1014.

Bradbury, J.P., Cumming, B.F., and Laird, K.R. 2002. A 1500-year record of climatic and environmental change in Elk Lake Minnesota III: measures of past primary productivity. J. Paleolimnol. 27: 321-340.

Brugam, R.B. 1979. A re-evaluation of the Araphidineae/Centrales index as an indicator of lake trophic status. Freshw. Biol. 9: 451-460.

Brugam, R.B., and Speziale, B.J. 1983. Human disturbance and the paleolimnological record of change in the zooplankton community of Lake Harriet, Minnesota. Ecology, 64: 578-591.

Charles, D.F., and Smol, J.P. 1994. Long-term chemical changes in lakes: quantitative inferences using biotic remains in the sediment record. In Environmental chemistry of lakes and reservoirs. Advances in Chemistry Series 237. Edited by L. Baker. American Chemical Society, Washington, D.C. pp. 1-31.

Cumming, B.F., Smol, J.P., Kingston, J.C., Charles, D.F., Birks, H.J.B., Camburn, K.E., Dixit, S.S., Uutala, A.J., and Selle, A.R. 1992. How much acidification has occurred in Adirondack region lakes (New York, U.S.A.) since preindustrial times? Can. J. Fish. Aquat. Sci. 49: 128-141.

Cumming, B.F., Davey, K.A., Smol, J.P., and Birks, H.J.B. 1994. When did acid-sensitive Adirondack lakes (New York, U.S.A.) begin to acidify and are they still acidifying? Can. J. Fish. Aquat. Sci. 51: $1550-1568$.

Dixit, S.S., Smol, J.P., Charles, D.F., Hughes, R.M., Paulsen, S.G., and Collins, G.B. 1999. Assessing water quality changes in the lakes of the northeastern United States using sediment diatoms. Can. J. Fish. Aquat. Sci. 56: 131-152.

Edmondson, W.T., and Lehman, J.T. 1981. The effect of changes in the nutrient income on the condition of Lake Washington. Limnol. Oceanogr. 26: 1-29.

Engstrom, D.R., Swain, E.B., and Kingston, J.C. 1985. A paleolimnological record of human disturbance from Harvey's Lake, Vermont: geochemistry, pigments and diatoms. Freshw. Biol. 15: 261-288.

Engstrom, D.R., Thommes, K., Balogh, S.J., Swain, E.B., and Post, H.A. 1999. Trends in atmospheric mercury deposition across Minnesota: evidence from dated sediment cores from 50 Minnesota lakes. Legislative Commission on Minnesota Resources, St. Paul, Minn.

Fritz, S.C. 1996. Paleolimnological records of climatic change in North America. Limnol. Oceanogr. 41: 882-889.

Fritz, S.C., Kingston, J.C., and Engstrom, D.R. 1993. Quantitative trophic reconstruction from sedimentary diatom assemblages: a cautionary tale. Freshw. Biol. 30: 1-23.

Hall, R.I., and Smol, J.P. 1992. A weighted-averaging regression and calibration model for inferring total phosphorus concentra- 
tion from diatoms in British Columbia (Canada) lakes. Freshw. Biol. 27: 417-434.

Hall, R.I., and Smol, J.P. 1996. Paleolimnological assessment of long-term water-quality changes in south-central Ontario lakes affected by cottage development and acidification. Can. J. Fish. Aquat. Sci. 53: 1-17.

Heiskary, S.A., Wilson, C.B., and Larsen, D.P. 1987. Analysis of regional patterns in lake water quality: using ecoregions for lake management in Minnesota. Lake Reservoir Manag. 3: 337-344.

Hodell, D.A., Schelske, C.L., Fahnenstiel, G.L., and Robbins, L.L. 1998. Biologically induced calcite and its isotopic composition in Lake Ontario. Limnol. Oceanogr. 43: 187-199.

Jassby, A.D., Goldman, C.R., and Reuter, J.E. 1995. Long-term changes in Lake Tahoe (California-Nevada, U.S.A.) and its relation to atmospheric deposition of algal nutrients. Arch. Hydrobiol. 135: 1-21.

Juggins, S., and ter Braak, C.J.F. 1992. CALIBRATE - a program for species-environment calibration by [weighted averaging] partial least squares regression. Environmental Change Research Centre, University College, London, U.K.

Kilham, S.S., Theriot, E.C., and Fritz, S.C. 1996. Linking planktonic diatoms and climate change using resource theory in the large lakes of the Yellowstone Ecosystem. Limnol. Oceanogr. 41: 1052-1062.

Kingston, J.C., Cook, R.B., Kreis, R.G., Camburn, K.E., Norton, S.A., Sweets, P.R., Binford, M.W., Mitchell, M.J., Schindler, S.C., Shane, L.C.K., and King, G.A. 1990. Paleoecological investigation of recent lake acidification in the northern Great Lakes states. J. Paleolimnol. 4: 153-201.

Krammer, K., and Lange-Bertalot, H. 1986-1991. Sufswasserflora von Mitteleuropa. Bd 2, Teil 1-4: Bacillariophyceae. Gustav Fischer Verlag, Stuttgart, Germany.

Laird, K.R., and Cumming, B.F. 2001. A regional paleolimnological assessment of the impact of clear-cutting on lakes from the central interior of British Columbia. Can. J. Fish. Aquat. Sci. 58: 492-505.

Lewis, W.M., Jr., Saunders, J.F., III, Crumpacker, D.W., Sr., and Brendecke, C.M. 1984. Eutrophication and land use, Lake Dillon, Colorado. Springer-Verlag, New York.

Minnesota Pollution Control Agency. 2000. Minnesota lake water quality assessment. Minnesota Pollution Control Agency, St. Paul, Minn.

Omernik, J.M. 1987. Ecoregions of the conterminous United States. Ann. Assoc. Am. Geogr. 77: 118-125.
Osburn, C.L., Morris, D.P., Thorn, K.A., and Moeller, R.E. 2001. Chemical and optical changes in freshwater dissolved organic matter exposed to solar radiation. Biogeochemistry, 54: 251-278.

Patrick, R., and Reimer, C.W. 1966. The diatoms of the United States. Monographic Series of Academy of Natural Sciences of Philadelphia No. 13. Livingston Publishing Company, Philadelphia, Pa.

Ramstack, J.M., Fritz, S.C., Engstrom, D.R., and Heiskary, S.A. 2003. The application of a diatom-based transfer function to evaluate regional water-quality trends in Minnesota since 1970. J. Paleolimnol. 29: 79-94.

Reavie, E.D., Hall, R.I., and Smol, J.P. 1995a. An expanded weighted-averaging model for inferring past total phosphorus concentrations from diatom assemblages in eutrophic British Columbia (Canada) lakes. J. Paleolimnol. 14: 49-67.

Reavie, E.D., Smol, J.P., and Carmichael, N.B. 1995b. Postsettlement eutrophication histories of six British Columbia (Canada) lakes. Can. J. Fish. Aquat. Sci. 52: 2388-2401.

Rohm, C.M., Omernik, J.M., and Kiilsgaard, C.W. 1995. Regional patterns of total phosphorus in the lakes of the northeastern United States. Lake Reservoir Manag. 11: 1-14.

Schindler, D.W., Bayley, S.E., Parker, B.R., Beaty, K.G., Cruikshank, D.R., Fee, E.J., Schindler, E.U., and Stainton, M.P. 1996. The effects of climatic warming on the properties of boreal lakes and streams at the Experimental Lakes Area, northwestern Ontario. Limnol. Oceanogr. 41: 1004-1017.

Siver, P.A., Lott, A.M., Cash, E., Moss, J., and Marsicano, L.J. 1999. Century changes in Connecticut, U.S.A., lakes as inferred from siliceous algal remains and their relationships to land-use change. Limnol. Oceanogr. 44: 1928-1935.

Swain, E.B., Engstrom, D.R., Brigham, M.E., Henning, T.A., and Brezonik, P.A. 1992. Increasing rates of atmospheric mercury deposition in midcontinental North America. Science (Wash., D.C.), 257: 784-787.

Tester, J.R. 1995. Minnesota's natural heritage, an ecological perspective. University of Minnesota Press, Minneapolis, Minn.

Williamson, C.E., Morris, D.P., Pace, M.L., and Olson, O.G. 1999. Dissolved organic carbon and nutrients as regulators of lake ecosystems: resurrection of a more integrated paradigm. Limnol. Oceanogr. 44: 795-803.

\section{Appendix A}

Tables A1 and A2 appear on the following pages. 
Table A1. Location and water quality characteristics of the study lakes (modified from Engstrom et al. 1999).

\begin{tabular}{|c|c|c|c|c|c|c|c|c|c|}
\hline Map No. & Ecoregion & County & Lake & Latitude, $\mathrm{N}$ & Longitude, W & $\mathrm{pH}$ & Color $(\mathrm{Pt}-\mathrm{Co})$ & $\mathrm{Cl}\left(\mathrm{mg} \cdot \mathrm{L}^{-1}\right)$ & $\mathrm{TP}\left(\mathrm{mg} \cdot \mathrm{L}^{-1}\right)$ \\
\hline 1 & Metro & Washington & Tanners & $44^{\circ} 57.00^{\prime}$ & $92^{\circ} 58.88^{\prime}$ & 8.9 & 26 & 99.0 & 0.056 \\
\hline 2 & Metro & Washington & Carver & $44^{\circ} 54.36^{\prime}$ & $92^{\circ} 58.83^{\prime}$ & 8.7 & 24 & 123.0 & 0.036 \\
\hline 3 & Metro & Washington & Elmo & $44^{\circ} 59.37^{\prime}$ & $92^{\circ} 52.96^{\prime}$ & 8.5 & 8 & 17.0 & 0.010 \\
\hline 5 & Metro & Washington & L. Carnelian & $45^{\circ} 07.07^{\prime}$ & $92^{\circ} 47.79^{\prime}$ & 8.8 & 7 & 8.3 & 0.009 \\
\hline 6 & Metro & Dakota & Dickman & $44^{\circ} 51.69^{\prime}$ & $93^{\circ} 04.74^{\prime}$ & 7.9 & 13 & 58.0 & 0.105 \\
\hline 7 & Metro & Dakota & Fish & $44^{\circ} 49.35^{\prime}$ & $93^{\circ} 10.03^{\prime}$ & 7.6 & 19 & 101.0 & 0.079 \\
\hline 8 & Metro & Dakota & Marcott & $44^{\circ} 48.95^{\prime}$ & $93^{\circ} 04.02^{\prime}$ & 7.8 & 10 & 36.0 & 0.019 \\
\hline 10 & Metro & Ramsey & Johanna & $45^{\circ} 02.43^{\prime}$ & $93^{\circ} 09.93^{\prime}$ & 8.2 & 17 & 119.0 & 0.036 \\
\hline 11 & Metro & Ramsey & Turtle & $45^{\circ} 06.22^{\prime}$ & $93^{\circ} 08.18^{\prime}$ & 8.3 & 8 & 22.0 & 0.027 \\
\hline 12 & Metro & Ramsey & Owasso & $45^{\circ} 02.28^{\prime}$ & $93^{\circ} 07.45^{\prime}$ & 8.1 & 15 & 81.0 & 0.040 \\
\hline 13 & Metro & Ramsey & McCarrons & $44^{\circ} 59.85^{\prime}$ & $93^{\circ} 06.67^{\prime}$ & 8.6 & 19 & 74.7 & 0.048 \\
\hline 14 & Metro & Ramsey & Gervais & $45^{\circ} 01.05^{\prime}$ & $93^{\circ} 04.30^{\prime}$ & 8.3 & 18 & 102.0 & 0.033 \\
\hline 15 & Metro & Hennepin & Calhoun & $44^{\circ} 56.63^{\prime}$ & $93^{\circ} 18.79^{\prime}$ & 8.7 & 9 & 117.0 & 0.028 \\
\hline 16 & Metro & Hennepin & Christmas & $44^{\circ} 53.85^{\prime}$ & $93^{\circ} 32.47^{\prime}$ & 8.9 & 7 & 23.0 & 0.015 \\
\hline 17 & Metro & Hennepin & Harriet & $44^{\circ} 55.15^{\prime}$ & $93^{\circ} 18.58^{\prime}$ & 8.9 & 9 & 96.0 & 0.027 \\
\hline 19 & Metro & Hennepin & Sweeney & $44^{\circ} 59.44^{\prime}$ & $93^{\circ} 20.48^{\prime}$ & 8.4 & 18 & 183.0 & 0.046 \\
\hline 20 & Metro & Hennepin & Twin & $44^{\circ} 59.52^{\prime}$ & $93^{\circ} 20.17^{\prime}$ & 8.5 & 14 & 100.0 & 0.022 \\
\hline 21 & NLF & Itasca (GR) & Forsythe & $47^{\circ} 15.97^{\prime}$ & $93^{\circ} 36.06^{\prime}$ & 6.9 & 85 & 0.7 & 0.021 \\
\hline 22 & NLF & Itasca (GR) & Snells & $47^{\circ} 14.46^{\prime}$ & $93^{\circ} 40.16^{\prime}$ & 8.2 & 18 & 6.3 & 0.024 \\
\hline 23 & NLF & Itasca (GR) & Long & $47^{\circ} 13.63^{\prime}$ & $93^{\circ} 39.39^{\prime}$ & 8.1 & 10 & 2.1 & 0.013 \\
\hline 24 & NLF & Itasca (GR) & Loon & $47^{\circ} 13.95^{\prime}$ & $93^{\circ} 38.42^{\prime}$ & 8.6 & 9 & 2.8 & 0.011 \\
\hline 25 & NLF & Itasca (GR) & Little Bass & $47^{\circ} 17.05^{\prime}$ & $93^{\circ} 36.09^{\prime}$ & 8.2 & 17 & 1.8 & 0.013 \\
\hline 26 & NLF & Cook (NS) & Dyers & $47^{\circ} 31.62^{\prime}$ & $90^{\circ} 58.79^{\prime}$ & 7.6 & 69 & 0.8 & 0.027 \\
\hline 27 & NLF & Lake (NS) & Tettegouche & $47^{\circ} 20.66^{\prime}$ & $91^{\circ} 16.18^{\prime}$ & 7.3 & 33 & 0.4 & 0.017 \\
\hline 28 & NLF & Lake (NS) & Nipisiquit & $47^{\circ} 21.31^{\prime}$ & $91^{\circ} 14.94^{\prime}$ & 7.4 & 23 & 0.3 & 0.016 \\
\hline 29 & NLF & Lake (NS) & Wolf & $47^{\circ} 22.61^{\prime}$ & $91^{\circ} 11.58^{\prime}$ & 7.8 & 18 & 1.9 & 0.014 \\
\hline 30 & NLF & Lake (NS) & Bear & $47^{\circ} 17.05^{\prime}$ & $91^{\circ} 20.62^{\prime}$ & 7.5 & 9 & 0.4 & 0.011 \\
\hline 31 & NLF & Lake (NS) & Bean & $47^{\circ} 18.51^{\prime}$ & $91^{\circ} 18.02^{\prime}$ & 7.6 & 8 & 0.3 & 0.017 \\
\hline 32 & NLF & Lake (SNF) & Ninemile & $47^{\circ} 34.55^{\prime}$ & $91^{\circ} 04.88^{\prime}$ & 7.4 & 17 & 0.8 & 0.017 \\
\hline 33 & NLF & Lake (SNF) & Wilson & $47^{\circ} 40.45^{\prime}$ & $91^{\circ} 04.53^{\prime}$ & 7.5 & 14 & 0.3 & 0.013 \\
\hline 34 & NLF & Lake (SNF) & Windy & $47^{\circ} 44.13^{\prime}$ & $91^{\circ} 04.31^{\prime}$ & 6.9 & 98 & 0.3 & 0.012 \\
\hline 35 & NLF & Lake (SNF) & August & $47^{\circ} 45.79^{\prime}$ & $91^{\circ} 36.37^{\prime}$ & 7.2 & 97 & 0.9 & 0.015 \\
\hline 39 & NLF & St. Louis (VNP) & Loiten & $48^{\circ} 31.60^{\prime}$ & $92^{\circ} 55.61^{\prime}$ & 7.1 & 29 & 0.3 & 0.008 \\
\hline 40 & NLF & St. Louis (VNP) & Tooth & $48^{\circ} 23.88^{\prime}$ & $92^{\circ} 38.59^{\prime}$ & 6.8 & 39 & 0.4 & 0.012 \\
\hline 41 & $\mathrm{NCHF}$ & Stearns (For) & Krighle & $45^{\circ} 34.72^{\prime}$ & $94^{\circ} 28.69^{\prime}$ & 8.5 & 3 & 1.2 & 0.011 \\
\hline 42 & NCHF & Stearns (For) & Sagatagan & $45^{\circ} 34.47^{\prime}$ & $94^{\circ} 23.45^{\prime}$ & 8.5 & 7 & 3.7 & 0.027 \\
\hline 43 & $\mathrm{NCHF}$ & Kandyohi (For) & George & $45^{\circ} 14.55^{\prime}$ & $94^{\circ} 59.06^{\prime}$ & 8.8 & 5 & 28.4 & 0.015 \\
\hline
\end{tabular}


Table A1 (concluded).

\begin{tabular}{|c|c|c|c|c|c|c|c|c|c|}
\hline Map No. & Ecoregion & County & Lake & Latitude, $\mathrm{N}$ & Longitude, W & $\mathrm{pH}$ & Color $(\mathrm{Pt}-\mathrm{Co})$ & $\mathrm{Cl}\left(\mathrm{mg} \cdot \mathrm{L}^{-1}\right)$ & $\mathrm{TP}\left(\mathrm{mg} \cdot \mathrm{L}^{-1}\right)$ \\
\hline 44 & NCHF & Kandyohi (For) & Long & $45^{\circ} 19.87^{\prime}$ & $94^{\circ} 51.13^{\prime}$ & 8.5 & 9 & 9.2 & 0.019 \\
\hline 45 & $\mathrm{NCHF}$ & Kandyohi (For) & Henderson & $45^{\circ} 13.82^{\prime}$ & $94^{\circ} 59.56^{\prime}$ & 8.6 & 7 & 17.6 & 0.022 \\
\hline 46 & NCHF & Kandyohi (Ag) & Diamond & $45^{\circ} 11.16^{\prime}$ & $94^{\circ} 51.23^{\prime}$ & 8.6 & 16 & 16.1 & 0.080 \\
\hline 47 & NCHF & Mcleod (Ag) & Hook & $44^{\circ} 57.21^{\prime}$ & $94^{\circ} 20.47^{\prime}$ & 8.4 & 15 & 25.3 & 0.068 \\
\hline 48 & $\mathrm{NCHF}$ & Mcleod (Ag) & Stahl & $44^{\circ} 57.18^{\prime}$ & $94^{\circ} 25.24^{\prime}$ & 8.4 & 20 & 11.6 & 0.046 \\
\hline 49 & $\mathrm{NCHF}$ & Meeker (Ag) & Dunns & $45^{\circ} 09.50^{\prime}$ & $94^{\circ} 25.74^{\prime}$ & 8.6 & 15 & 17.5 & 0.139 \\
\hline 50 & NCHF & Meeker (Ag) & Richardson & $45^{\circ} 09.57^{\prime}$ & $94^{\circ} 26.40^{\prime}$ & 8.3 & 18 & 17.4 & 0.098 \\
\hline 51 & WCBP & Jackson & Fish & $43^{\circ} 50.82^{\prime}$ & $95^{\circ} 02.67^{\prime}$ & 8.8 & 9 & 20.2 & 0.038 \\
\hline 52 & WCBP & Faribault & Bass & $43^{\circ} 49.22^{\prime}$ & $94^{\circ} 04.67^{\prime}$ & 9.0 & 20 & 15.0 & 0.081 \\
\hline 53 & WCBP & Blue Earth & Duck & $44^{\circ} 13.07^{\prime}$ & $93^{\circ} 48.89^{\prime}$ & 8.9 & 12 & 16.2 & 0.065 \\
\hline 54 & WCBP & Blue Earth & George & $44^{\circ} 14.02^{\prime}$ & $93^{\circ} 52.29^{\prime}$ & 9.2 & 25 & 11.2 & 0.130 \\
\hline 55 & WCBP & Steele & Beaver & $43^{\circ} 53.52^{\prime}$ & $93^{\circ} 20.90^{\prime}$ & 8.9 & 9 & 15.0 & 0.030 \\
\hline
\end{tabular}

Note: Metro, Twin Cities metropolitan area; NLF, Northern Lakes and Forests ecoregion (GR, Grand Rapids; NS, North Shore; SNF, Superior National Forest; VNP, Voyageurs National Park);

NCHF, North Central Hardwood Forests ecoregion (For, watershed is primarily forested; Ag, agriculturally dominated watershed); WCBP, Western Corn Belt Plains ecoregion (refer to text for description of regions).

Table A2. Geomorphic and land-use characteristics of the study lakes (modified from Engstrom et al. 1999).

\begin{tabular}{|c|c|c|c|c|c|c|c|c|c|c|}
\hline Map No. & Ecoregion & Lake & Max. depth (m) & Lake area $(\mathrm{Ha})$ & Catchment area $(\mathrm{Ha})$ & Catchment to lake area & $\%$ built up & $\%$ agriculture & $\%$ forest & $\%$ road \\
\hline 1 & Metro & Tanners & 13.7 & 30.2 & 669.4 & 22.2 & 76.2 & 0.0 & 2.0 & 7.7 \\
\hline 2 & Metro & Carver & 11.0 & 19.6 & 864.0 & 44.1 & 51.2 & 17.8 & 11.5 & 5.6 \\
\hline 3 & Metro & Elmo & 42.7 & 114.6 & 2075.6 & 18.1 & 10.0 & 50.8 & 11.5 & 0.9 \\
\hline 4 & Metro & Square & 20.7 & 81.9 & 226.0 & 2.8 & 10.3 & 15.0 & 33.6 & 1.7 \\
\hline 5 & Metro & L. Carnelian & 19.2 & 46.7 & 1853.8 & 39.7 & 10.1 & 17.1 & 34.0 & 0.8 \\
\hline 6 & Metro & Dickman & 2.4 & 9.1 & 56.9 & 6.2 & 33.0 & 8.9 & 26.9 & 1.9 \\
\hline 7 & Metro & Fish & 10.1 & 12.5 & 1505.6 & 120.8 & 86.1 & 0.0 & 1.0 & 5.3 \\
\hline 8 & Metro & Marcott & 10.1 & 7.5 & 251.0 & 33.6 & 9.6 & 30.6 & 32.6 & 0.2 \\
\hline 9 & Metro & Schultz & 4.9 & 5.3 & 69.1 & 13.1 & 1.6 & 0.0 & 67.0 & 0.0 \\
\hline 10 & Metro & Johanna & 12.5 & 86.4 & 1025.9 & 11.9 & 67.1 & 0.0 & 2.9 & 7.1 \\
\hline 11 & Metro & Turtle & 8.8 & 133.3 & 180.3 & 1.4 & 46.0 & 0.0 & 0.0 & 1.5 \\
\hline 12 & Metro & Owasso & 12.2 & 150.9 & 423.0 & 2.8 & 47.5 & 0.0 & 2.5 & 3.0 \\
\hline 13 & Metro & McCarrons & 17.4 & 30.1 & 412.1 & 13.7 & 57.8 & 0.0 & 0.0 & 3.9 \\
\hline 14 & Metro & Gervais & 12.5 & 94.4 & 4028.0 & 42.7 & 55.6 & 0.0 & 4.3 & 7.5 \\
\hline 15 & Metro & Calhoun & 27.4 & 168.5 & 2515.1 & 14.9 & 83.9 & 0.0 & 0.8 & 9.8 \\
\hline 16 & Metro & Christmas & 26.5 & 105.7 & 189.3 & 1.8 & 54.9 & 1.3 & 3.3 & 2.9 \\
\hline 17 & Metro & Harriet & 25.0 & 138.6 & 387.3 & 2.8 & 66.7 & 0.0 & 6.1 & 7.8 \\
\hline 18 & Metro & Little Long & 23.2 & 21.8 & 32.4 & 1.5 & 0.0 & 10.7 & 34.6 & 1.2 \\
\hline 19 & Metro & Sweeney & 7.6 & 28.3 & 1010.9 & 35.7 & 64.7 & 0.0 & 6.6 & 1.2 \\
\hline
\end{tabular}


Table A2 (concluded).

\begin{tabular}{|c|c|c|c|c|c|c|c|c|c|c|}
\hline Map No. & Ecoregion & Lake & Max. depth (m) & Lake area $(\mathrm{Ha})$ & Catchment area $(\mathrm{Ha})$ & Catchment to lake area & $\%$ built up & $\%$ agriculture & $\%$ forest & $\%$ road \\
\hline 20 & Metro & Twin & 17.1 & 8.7 & 33.5 & 3.8 & 28.4 & 0.0 & 46.3 & 4.3 \\
\hline 21 & NLF & Forsythe & 3.1 & 27.1 & 191.2 & 7.1 & 0.0 & 4.5 & 44.1 & 0.8 \\
\hline 22 & NLF & Snells & 15.2 & 35.8 & 288.2 & 8.1 & 0.0 & 38.6 & 44.2 & 1.1 \\
\hline 23 & NLF & Long & 22.9 & 54.5 & 164.7 & 3.0 & 0.1 & 6.4 & 54.3 & 1.0 \\
\hline 24 & NLF & Loon & 21.0 & 92.9 & 363.6 & 3.9 & 4.4 & 13.0 & 38.4 & 1.3 \\
\hline 25 & NLF & Little Bass & 18.9 & 64.5 & 540.1 & 8.4 & 4.2 & 9.8 & 54.6 & 0.7 \\
\hline 26 & NLF & Dyers & 6.1 & 27.8 & 854.2 & 30.7 & 0.0 & 0.0 & 89.3 & 0.6 \\
\hline 27 & NLF & Tettegouche & 4.6 & 26.7 & 102.7 & 3.8 & 0.0 & 0.0 & 76.6 & 0.0 \\
\hline 28 & NLF & Nipisiquit & 5.5 & 23.7 & 297.7 & 12.6 & 0.0 & 0.0 & 71.4 & 0.0 \\
\hline 29 & NLF & Wolf & 7.3 & 13.1 & 67.9 & 5.2 & 4.7 & 0.0 & 77.0 & 0.0 \\
\hline 30 & NLF & Bear & 8.8 & 18.3 & 60.0 & 3.3 & 0.0 & 0.0 & 76.6 & 0.0 \\
\hline 31 & NLF & Bean & 7.9 & 12.5 & 64.3 & 5.1 & 0.0 & 0.0 & 73.1 & 0.0 \\
\hline 32 & NLF & Ninemile & 9.1 & 120.3 & 209.0 & 1.7 & 0.0 & 0.0 & 63.5 & 0.3 \\
\hline 33 & NLF & Wilson & 14.9 & 257.1 & 718.9 & 2.8 & 0.0 & 0.0 & 61.3 & 0.0 \\
\hline 34 & NLF & Windy & 11.9 & 184.6 & 1705.0 & 9.2 & 0.0 & 0.0 & 69.1 & 0.3 \\
\hline 35 & NLF & August & 5.8 & 76.5 & 936.8 & 12.3 & 0.0 & 0.0 & 76.2 & 0.3 \\
\hline 36 & NLF & Shoepack & 7.3 & 155.4 & 1767.9 & 11.4 & 0.0 & 0.0 & 68.2 & 0.0 \\
\hline 37 & NLF & Little Trout & 29.0 & 107.6 & 139.8 & 1.3 & 0.0 & 0.0 & 56.6 & 0.0 \\
\hline 38 & NLF & Locator & 15.9 & 54.1 & 1489.4 & 27.5 & 0.0 & 0.0 & 81.1 & 0.0 \\
\hline 39 & NLF & Loiten & 14.9 & 39.0 & 241.7 & 6.2 & 0.0 & 0.0 & 80.8 & 0.0 \\
\hline 40 & NLF & Tooth & 13.1 & 23.6 & 151.0 & 6.4 & 0.0 & 0.0 & 78.0 & 0.0 \\
\hline 41 & $\mathrm{NCHF}$ & Kreighle & 17.1 & 41.0 & 87.8 & 2.1 & 0.0 & 15.7 & 48.6 & 1.1 \\
\hline 42 & $\mathrm{NCHF}$ & Sagatagan & 14.3 & 88.7 & 251.8 & 2.8 & 1.7 & 16.3 & 43.4 & 0.7 \\
\hline 43 & $\mathrm{NCHF}$ & George & 9.1 & 91.6 & 102.2 & 1.1 & 21.0 & 1.9 & 17.3 & 0.6 \\
\hline 44 & $\mathrm{NCHF}$ & Long & 13.4 & 129.8 & 362.7 & 2.8 & 12.0 & 26.0 & 24.1 & 0.8 \\
\hline 45 & $\mathrm{NCHF}$ & Henderson & 12.2 & 29.1 & 59.4 & 2.0 & 24.0 & 18.5 & 7.7 & 3.4 \\
\hline 46 & $\mathrm{NCHF}$ & Diamond & 8.2 & 644.8 & 3589.7 & 5.6 & 4.5 & 56.4 & 4.3 & 0.9 \\
\hline 47 & $\mathrm{NCHF}$ & Hook & 5.5 & 133.1 & 620.1 & 4.7 & 3.3 & 61.0 & 4.3 & 0.5 \\
\hline 48 & $\mathrm{NCHF}$ & Stahl & 10.7 & 54.6 & 629.6 & 11.5 & 0.0 & 55.6 & 11.0 & 1.2 \\
\hline 49 & $\mathrm{NCHF}$ & Dunns & 6.1 & 63.0 & 1381.3 & 21.9 & 7.7 & 50.2 & 11.2 & 1.2 \\
\hline 50 & $\mathrm{NCHF}$ & Richardson & 14.3 & 48.3 & 1168.5 & 24.2 & 2.4 & 73.1 & 4.1 & 1.0 \\
\hline 51 & WCBP & Fish & 8.2 & 120.7 & 649.4 & 5.4 & 1.5 & 76.0 & 3.2 & 1.0 \\
\hline 52 & WCBP & Bass & 6.1 & 75.7 & 136.5 & 1.8 & 9.5 & 44.8 & 6.8 & 1.0 \\
\hline 53 & WCBP & Duck & 7.6 & 116.6 & 385.0 & 3.3 & 3.0 & 66.2 & 1.3 & 1.2 \\
\hline 54 & WCBP & George & 8.5 & 36.2 & 54.4 & 1.5 & 0.0 & 48.8 & 11.1 & 1.1 \\
\hline 55 & WCBP & Beaver & 8.2 & 37.8 & 71.1 & 1.9 & 9.5 & 39.7 & 15.6 & 1.6 \\
\hline
\end{tabular}
( text for description of regions). Max., maximum. 
Copyright of Canadian Journal of Fisheries \& Aquatic Sciences is the property of NRC Research Press and its content may not be copied or emailed to multiple sites or posted to a listserv without the copyright holder's express written permission. However, users may print, download, or email articles for individual use. 